EESTI NSV TEADUSTE AKADEEMIA TOIMETISED. 23. KOIDE KEEMIA * GEOLOOGIA. 1974, NR. 4

ИЗВЕСТИЯ АКАДЕМИИ НАУК ЭСТОНСКОИ ССР. ТОМ 23 ХИМИЯ * ГЕОЛОГИЯ. 1974, № 4

\title{
DISCOVERY OF NEW DEVONIAN FISH LOCALITIES IN THE SOVIET ARCTIC
}

Comparatively few Devonian vertebrate localities have been reported from the enormous territory of North Siberia. They are known from the north-west of the Siberian platform and Kolyma basin, Taimyr and Chukchi Peninsulas and Novaya and Severnaya Zemlya Archipelagos. In 1972, Devonian fishes were found on Kotelny Island, the New Siberian Archipelago. In the north-western part of the island the folded Paleozoic, mostly Devonian and Silurian rocks occur. The Devonian consists of marine deposits well exposed along the coast in the up to 30-metrehigh cliffs. Of the four localities discovered, three are of the Early Devonian and one of the Late Devonian age. They are dated on the basis of invertebrates by S. V. Cherkesova (Institute of Geology of the Arctic, NIIGA). As to the vertebrates, most of them seem to be represented by new forms; some may be the earliest known members of the groups (Ptyctodontida, Palaeonisci).

1. The richest locality is on the Rybnay a brook, north-east of the Bysakh-Karga River. The vertebrate-bearing layer of 0.30 -metre-thick dark-brown shale occurs in grey limestones and dolomites with abundant brachiopods, tabulata, ostracods, trilobites, gastropods, etc. The shale contains ostracods, inarticulated brachiopods, pelecypods, some tabulata and merostomata (fragments). The vertebrates include Heterostraci, Arthrodira, Acanthodii, Crossopterygii and Palaeonisci. Heterostracans, represented by an amphiaspid Gerronaspis sp. (Text-fig. 1, P1. I, Fig. 1) and a form related to pteraspids? (Text-fig. 2) are rare. Arthrodires are most numerous. A paleacanthaspid (Pl. II, Fig. 1) and a ptyctodont are small. A third, comparatively small arthrodire may belong to arctolepids. A fourth form with large tubercles is perhaps a coccosteomorph (PI. II, Fig. 2). Several bones (Text-fig. 3, Pl. I, Fig. 2) and some articulated trunk-shields (P1. I, Fig. 3) belong to the ptyctodont with short free lateral spines and weakly developed crest on median dorsal plate. The acanthodian jaw bone (Text-fig. 4) roughly agrees with Atopacanthus jaw bones of type A (Ørvig, 1957; P1. 2, Figs. 1, 2) with lateral and medial rows of teeth. The porolepid scales (Text-fig. 5, P1. II, Figs. 3, 4), rather common, are of the Siberian type (Воробьева, 1963). They have a stripe of dentine tubercles anterior to the cosmine-covered free surface. The latter is devoid of ridges in its anterior part. The scales are provisionally identified as those of Porolepis kureikensis Vorobyeva. There are small cycloid scales of another crossopterygian (Pl. II, Fig. 5). The paleoniscid scales (Text-fig. 6, Pl. II, Fig. 6) reveal some similarities to 


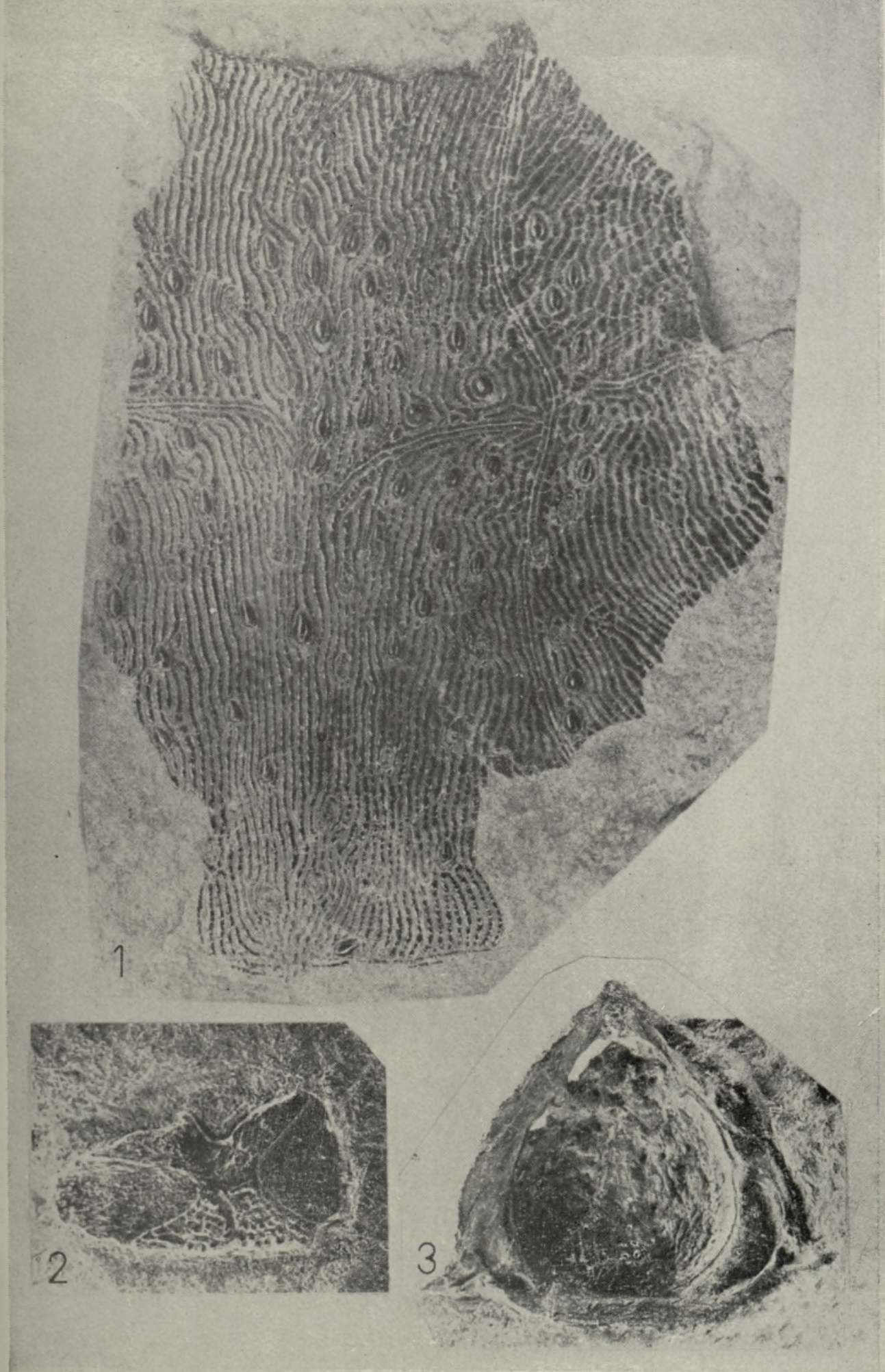

P l a te I. Fig. 1. Amphiaspid Gerronaspis sp., fragment of dorsal shield (cf. Text-fig. 1), $\times 4$ approx. Fig. 2. Anterior dorsolateral plate of ptyctodont (cf. Text-fig. 3), $\times 8$. Fig. 3 . Trunk-shield of ptyctodont, posterior view, $\times 4$. All specimens from Rybnaya, Kotelny Island; Early Devonian, Gedinnian. 


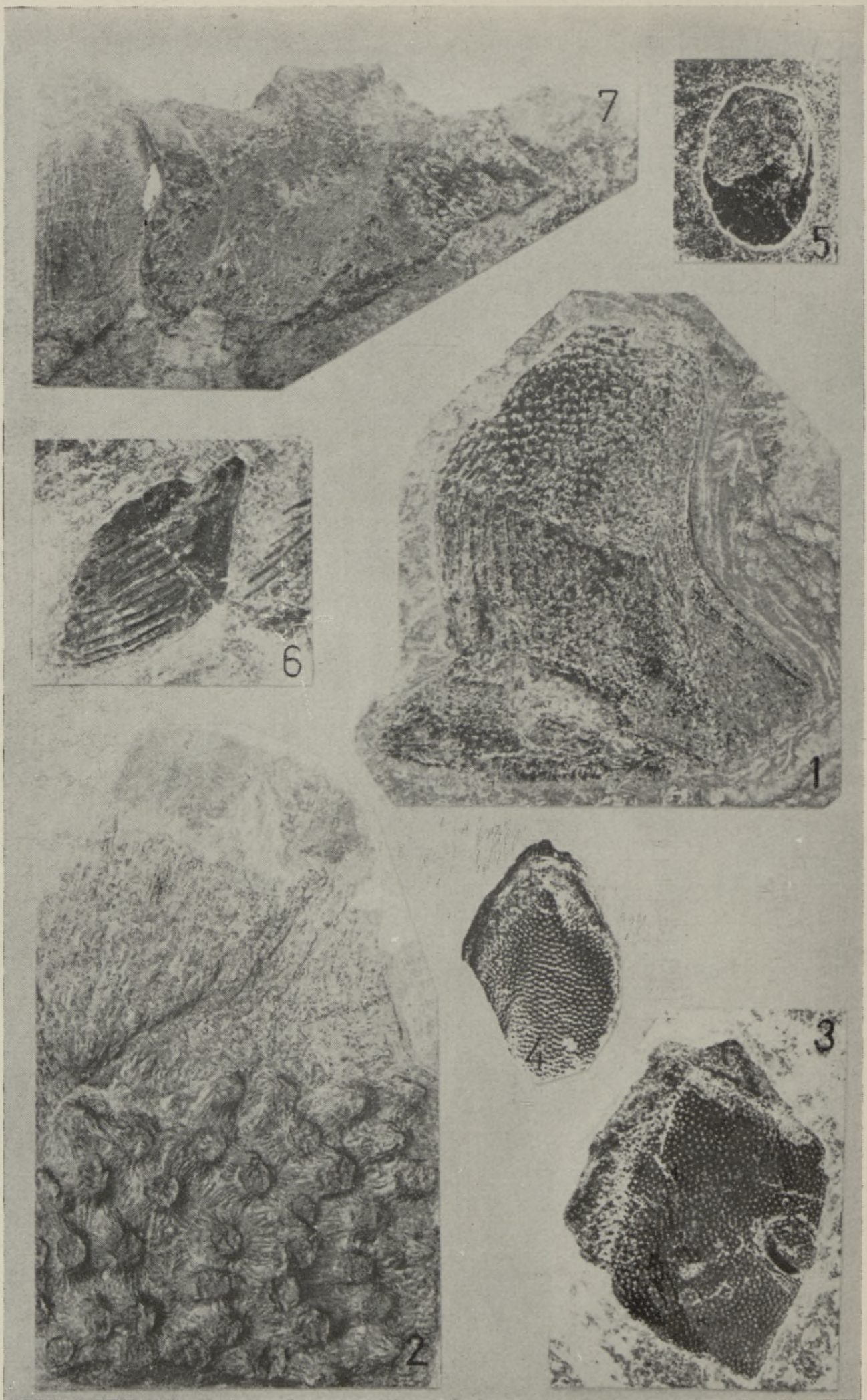

P 1 a te II. Fig. 1. Anterior lateral and spinal plate of paleacanthaspid. Fig. 2. Fragment of coccosteomorph arthrodire. Fig. 3, 4. Scales of porolepid (Fig. 3 cf. Text-fig. 5), Fig. 5. Cycloid scale of crossopterygian. Fig. 6. Scale of paleoniscid. All figures $\times 4$. Rybnaya. Fig. 7. Anterior dorsolateral plate of arctolepid (?) arthrodire, visceral view (cf. Text-fig. 9), $\times 4$. Sokolova (north of the river mouth). Kotelny Island; Early Devonian, Gedinnian. 


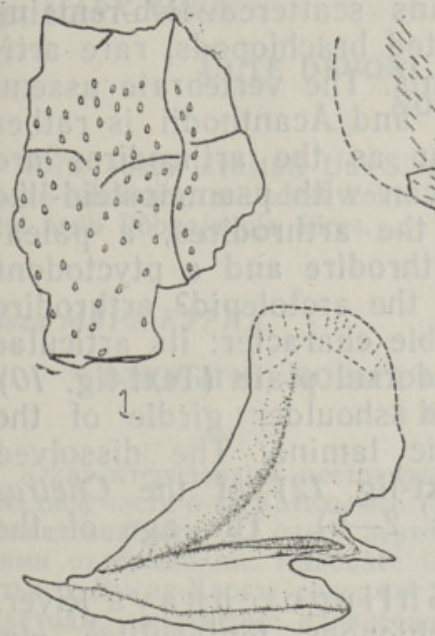

8

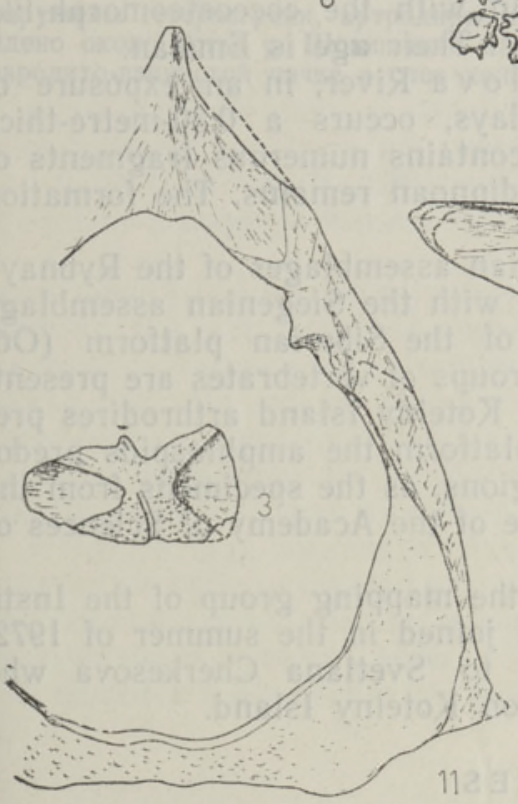

11
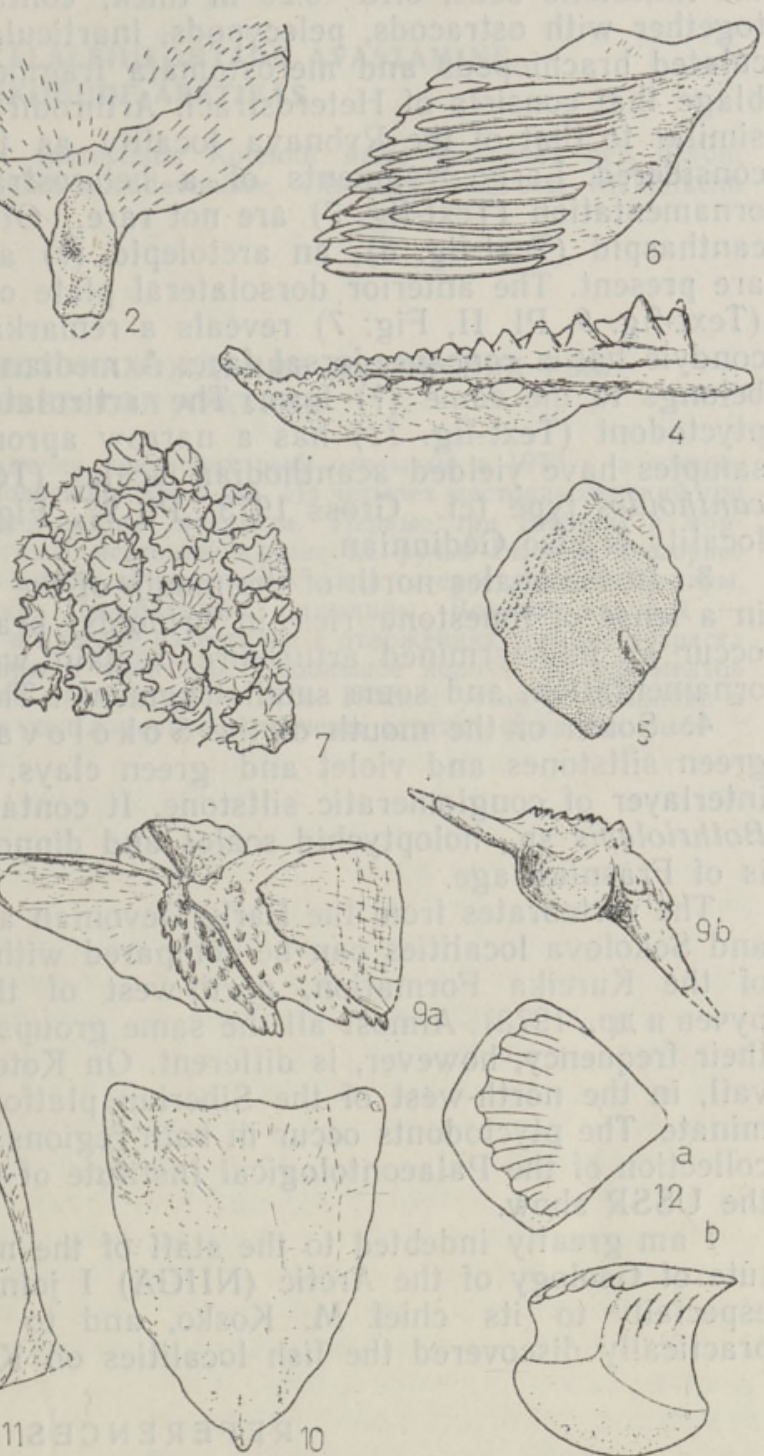

Text-figures. 1 - Amphiaspid Gerronaspis sp., fragment of dorsal shield (sensory canals and commissures and large tubercles indicated), $\times 1$ approx. 2 - Heterostracan, posterior portion of dorsal shield, visceral view, $\times 0,5.3$ - Anterior dorsolateral plate of ptyctodont, $\times 4$. 4 - Acanthodian jaw bone, $\times 2,5.5-$ Porolepid scale, $\times 2$. $6-$ Paleoniscid scale, $\times 5.7$ - Heterostracan, fragment with psammosteid-type ornamentation, $\times 10,8-$ Lateral and ventral face of paleacanthaspid trunk-shield, $\times 3,9-$ Anterior dorsolateral plate of the arctolepid (?) arthrodire; $(a)$ external and $(b)$ anterior view, $\times 2.10-$ Median dorsal plate of arctolepid (?), $\times 2.11-$ Trunk-shield of ptyctodont, anterior view, $\times 5,12$ - Acanthodian scale $(a)$ superficial and (b) lateral view, $\times 40$. Text-figs. $1-6$ : Rybnaya; Text-figs. $7-12$ : Sokolova (north of the river mouth). Early Devonian, Gedinnian.

those of the early paleoniscid Dialipina (Schultze, 1968). The age of the finds is Gedinnian.

2. North of the mouth of the Sokolova River, a limestone and shale formation with a rich invertebrate assemblage is exposed. One of

5 ENSV TA Toimetised. $\mathrm{K} * \mathrm{G}-41974$ 
the limestone beds, $0.15-0.20 \mathrm{~m}$ thick, contains scattered fish-remains together with ostracods, pelecypods, inarticulated brachiopods, rare articulated brachiopods and merostomata fragments. The vertebrate assemblage that consists of Heterostraci, Arthrodira and Acanthodii is rather similar to that of the Rybnaya locality as far as the arthrodires are considered. Large fragments of a heterostracan with psammosteid-like ornamentation (Text-fig. 7) are not rare. Of the arthrodires, a paleacanthaspid (Text-fig. 8), an arctolepid (?) arthrodire and a ptyctodont are present. The anterior dorsolateral plate of the arctolepid? arthrodire (Text-fig. 9, Pl. II, Fig: 7) reveals a remarkable character: its articular condyle has a concave dorsal face. A median dorsal plate (Text-fig. 10) belongs to the same (?) form. The articulated shoulder girdle of the ptyctodont (Text-fig. 11) has a narrow apronic lamina. The dissolved samples have yielded acanthodian scales (Text-fig. 12) of the Cheiracanthoides type (cf. Gross 1973, Pl. 27, Figs. 2-6). The age of the locality is also Gedinnian.

3. In the shales north of the mouth of the Shliupotchnay a River, in a lense of limestone rich in crinoids, brachiopods, tentaculites, etc. occur an undetermined arthrodire remain with the coccosteomorph-like ornamentation, and some small fragments. Their age is Emsian.

4. South of the mouth of the Sokolova River, in an exposure of green siltstones and violet and green clays, occurs a 0.30 -metre-thick interlayer of conglomeratic siltstone. It contains numerous fragments of Bothriolepis sp., holoptychid scales and dipnoan remains. The formation is of Frasnian age.

The vertebrates from the Early Devonian assemblages of the Rybnaya and Sokolova localities can be compared with the Siegenian assemblage of the Kureika Formation, north-west of the Siberian platform (Oбручев и др., 1973). Almost all the same groups of vertebrates are present; their frequency, however, is different. On Kotelny Island arthrodires prevail, in the north-west of the Siberian platform the amphiaspids predominate. The ptyctodonts occur in both regions, as the specimens from the collection of the Palaeontological Institute of the Academy of Sciences of the USSR show.

I am greatly indebted to the staff of the mapping group of the Institute of Geology of the Arctic (NIIGA) I joined in the summer of 1972, especially to its chief $M$. Kosko, and to Svetlana Cherkesova who practically discovered the fish localities on Kotelny Island.

\section{REFERENCES}

Gross W. 1973. Kleinschuppen, Flossenstacheln und Zähne von Fischen aus europäischen und nordamerikanischen Bonebeds des Devons. Palaeontographica A, 142, Lfg. $4-6$.

О бручев Д. В. Ч еркесов а С. В., Меннер В. В., Новицкая Л. И., П а т у н ов Д. К., 1973. Корреляция нижнедевонских толщ юго-западного Таймыра ін Сибирской платформы по брахиоподам и позвоночным. В сб.: Стратиграфия нижнего и среднего девона. Тр. III междунар. симп. по границе снл, и дев. и стратигр. нижн. и ср. девона, т. II.

Ørvig T. 1957. Notes on some Paleozoic lower vertebrates from Spitsbergen and North America. Norsk geol. tidssk., 37, h. 3-4,

Schultze H. P. 1968. Palaeoniscoidea-Schuppen aus dem Unterdevon Australiens und Kanadas und aus dem Mitteldevon Spitzbergens. Bull. Br. Mus. (Nat. Hist.) Geol., 16, No. 7.

В оробьева Е. И. 1963. О кистеперых рыбах рода Porolepis из девона СССР Палеонт. Ж., № 2. 
Elga MARK-KURIK

\section{UUTE DEVONI KALALEIUKOHTADE AVASTAMINE NOUKOGUDE ARKTIKAS}

1972. aastal avastati Uus-Siberi saarestikus Kotelnōi saare loodeosas neli devoni kalade leiukohta, milledest kolm kuulub alamdevonisse, üks ülemdevonisse. Rikkalikeim neist asub Rōbnaja oja ääres.

\section{Эльга МАРК-КУРИК}

\section{ОТКРЫТИЕ НОВЫХ МЕСТОНАХОЖДЕНИИ ДЕВОНСКИХ РЫБ В СОВЕТСКОИ АРКТИКЕ}

Охарактеризованы местонахождения девонских рыб, открытые в 1972 г. в северозападной части о-ва Котельного (Новосибирские о-ва). Из четырех местонахождений три нижнедевонского и одно верхнедевонского возраста. Первые три связаны с морскими отложениями. Наиболее богатое местонахождение на ручье Рыбном (севернее устья р. Бысах-Карга) содержит в одном из прослоев сланца гетеростраки, артродиры, акантоды, кистеперые и палеониски. Преобладают артродиры. Возраст находок жедин. Севернее устья р. Соколова в прослое известняка в отложениях того же возраста обнаружены гетеростраки, артродиры и акантоды. Небольшое количество фрагментов найдено около устья р. Шлюпочная в известняках эмса. Южнее устья р. Соколова в алевролито-глинистой пачке в слое конгломерата встречены остатки франских рыб. 